\title{
The Composition and Structure of Ferrospheres Formed by Industrial Combustion of Ekibastuz Coal
}

\author{
Olga M. Sharonova*, \\ Marina A. Fedorchak and Elena V. Mazurova \\ Institute of Chemistry and Chemical Technology SB RAS \\ FRC "Krasnoyarsk Science Center SB RAS" \\ 50/24 Akademgorodok, Krasnoyarsk, 660036, Russia
}

Received 20.02.2017, received in revised form 29.03.2017, accepted 02.06.2017

\begin{abstract}
The ferrospheres recovered from industrial fly ash of Ekibastuz coal have been studied in the form of high-purity fractions. It is found that the main phase of ferrospheres is a ferrite spinel (46-49\%), in which a part of iron is replaced by $\mathrm{Al}$ and $\mathrm{Mg}$, as evidenced by the lower lattice parameter as compared with magnetite. A major amount of the silicon, aluminum and a substantial amount of the iron are included in amorphous substance of ferrospheres constituting 41-42\% in the studied fractions. Three types offerrospheres (dendritic, block-like and dendritic-block structure) constituting about $80 \%$ of the studied fractions have been investigated by SEM-EDS. It was found that the gross compositions of these ferrospheres correspond to a relatively low melting (1100-1300 ${ }^{\circ} \mathrm{C}$ ) composition points located on the border areas of crystallization for wustite, fayalite, ferrous cordierite and hercynite in the $\mathrm{FeO}-\mathrm{Al}_{2} \mathrm{O}_{3}-\mathrm{SiO}_{2}$ ternary diagram. The predominant type of globules is dendritic (48-63\%), they consist of a thin unidirectional individuals or branched crystalline Al, Mg-ferrite spinel. Dendritic crystals contain Mg 2-3 times and Al 1.1-2.1 times higher compared with the amorphous regions. Block-like ferrospheres having a similar composition with dendritic globules consist of large, high-iron blocks of ferrospinels, in which $\mathrm{Mg}$ and Al content in the 2-4 times lower than in the interblock amorphous substance. An important factor influencing the structure ferrospheres is the dispersion of their main precursor-siderite $\mathrm{FeCO}_{3}$.
\end{abstract}

Keywords: ferrospheres, composition, structure.

DOI: $10.17516 / 1998-2836-0016$.

(C) Siberian Federal University. All rights reserved

* Corresponding author E-mail address: sharon05@yandex.ru 


\title{
Состав и строение ферросфер, образованных при промышленном сжигании угля Экибастузского бассейна
}

\author{
О.М. Шаронова, М.А. Федорчак, Е.В. Мазурова \\ Институт химии и химической технологии СО РАН \\ ФИЦ «Красноярский научныий иенттр СО РАН» \\ Россия, 660036, Красноярск, Академгородок, 50/24
}

Изучены ферросферы, полученные в виде фракций высокой чистоты из промышленной летучей золь каменного угля Экибастузского бассейна. Установлено, что главной фазой ферросфер является феррошпинель (46-49 \%), в которой часть железа замещена на Al и $\mathrm{Mg}$, о чем свидетельствует более низкий параметр кристаллической решетки по сравнению с магнетитом. Основная часть кремния, алюминия и значительная часть железа входят в состав аморфного вещества ферросфер, составляющего 41-42 \% в изученных фракциях. Методами сканирующей электронной микроскопии и энергодисперсионной рентгеновской спектроскопии исследованы ферросферы трех типов (дендритного, блочного и дендритноблочного строения), составляющие около 80 \% изученных фракиий. Установлено, что брутто-составы этих ферросфер соответствуют относительно низкоплавким (1100$1300{ }^{\circ} \mathrm{C}$ ) составам, находящимся на границах областей кристаллизации вюстита, фаялита, железистого кордиерита, гериинита в тройной диаграмме состояния $\mathrm{FeO}-\mathrm{Al}_{2} \mathrm{O}_{3}-\mathrm{SiO}_{2}$. Превалируюшим типом глобул являются дендритные (48-63\%), которые состоят из тонких однонаправленных или разветвленных кристаллических индивидов Al, Mg-ферритовой шпинели. Дендритные кристаллы содержат Mg в 2-3 раза и Al в 1,1-2,1 раза выме по сравнению с участками аморфного вещества. Блочные ферросферы, имеющие близкий состав с дендритными глобулами, состоят из крупных высокожелезистых блоков феррошпинели, в которых содержание $\mathrm{Mg}$ и $\mathrm{Al}$ в 2-4 раза ниже, чем в межблочном аморфном веществе. Важным фактором, влияющим на строение ферросфер, выступает дисперсность их главного прекурсора - сидерита $\mathrm{FeCO}_{3}$.

Ключевые слова: ферросферы, состав, строение.

\section{Введение}

Из энергетических углей, применяемых на теплоэлектростанциях России, уголь Экибастузского бассейна имеет самую высокую зольность - 41-45 \% [1, 2], что приводит к быстрому накоплению отходов от его промышленного сжигания и побуждает к поиску способов их сокращения путем переработки в ценные продукты. К таким продуктам относится, в частности, магнитный концентрат ферросфер, для которого отработаны способы выделения и определены области промышленного применения [2-4]. Более наукоемкими и дорогостоящими являются функциональные материалы на основе узких фракций ферросфер, разрабатываемые для при- 
менения в качестве катализаторов окислительного превращения метана [5], в термолизе нефтяных остатков [6], для получения аффинных сорбентов [7].

Исследование узких фракций ферросфер, полученных из четырех известных типов зол - $\mathrm{S}$ (алюмосиликатного), FS (железоалюмосиликатного), CS (кальцийалюмосиликатного), FCS (железокальцийалюмосиликатного), - позволило определить составы фракций, характерные для зол разного типа, и установить взаимосвязь состав - строение глобул в интервале содержания общего железа 30-92 мас. \% $\mathrm{Fe}_{2} \mathrm{O}_{3}[8,9]$. Состав фракций ферросфер золы экибастузского угля, относящейся к типу S, находится в интервале содержания общего железа 36-71 мас. \% $\mathrm{Fe}_{2} \mathrm{O}_{3}$, к числу основных компонентов относятся также $\mathrm{SiO}_{2}$ и $\mathrm{Al}_{2} \mathrm{O}_{3}$, так что сумма $\mathrm{Fe}_{2} \mathrm{O}_{3}+\mathrm{SiO}_{2}+\mathrm{Al}_{2} \mathrm{O}_{3}$ в изученных фракциях равна 92-99 мас. \%.

В минеральной части экибастузских углей преобладают глинистые минералы, преимущественно состава каолинита $\mathrm{Al}_{2} \mathrm{Si}_{2} \mathrm{O}_{5}(\mathrm{OH})_{4}$, содержится значительное количество кварца $\alpha-\mathrm{SiO}_{2}$ и карбонатов - сидерита $\mathrm{FeCO}_{3}$, кальцита $\mathrm{CaCO}_{3}$, магнезита $\mathrm{MgCO}_{3}$ [2, 10-12]. В качестве примесей присутствуют гидрослюды типа иллита $\mathrm{K}_{0.75}\left(\mathrm{Al}_{1.75}(\mathrm{Fe}, \mathrm{Mg}, \mathrm{Ti})_{0.25}\right)\left(\mathrm{Si}_{3.5} \mathrm{Al}_{0.5}\right) \mathrm{O}_{10}(\mathrm{OH})_{2}$, полевые шпаты, доломит $\mathrm{Ca}, \mathrm{Mg}\left(\mathrm{CO}_{3}\right)_{2}$, пирит $\mathrm{FeS}_{2}$, магнетит $\mathrm{Fe}_{3} \mathrm{O}_{4}[10,12]$. По данным рентгенофазового анализа $[11,12]$, минеральная часть экибастузских углей представлена следующими компонентами (мас. \%): каолинит -54 , кварц -28 , сидерит -10 , кальцит -5 , гипс -2 и магнезит -1 . При этом для угля Экибастузского бассейна характерно тонкодисперсное распределение минеральных компонентов в органической массе [10, 11], поэтому методы обогащения вследствие их низкой эффективности не применяются. Основной железосодержащий минерал - сидерит $\mathrm{FeCO}_{3}[2,10-12]$, который является главным прекурсором ферросфер.

В условиях сжигания экибастузского угля при температурах $1600-1700{ }^{\circ} \mathrm{C}$ в восстановительной атмосфере образование ферросфер происходит из расплавов, компонентный состав которых определяется системой $\mathrm{FeO}-\mathrm{Al}_{2} \mathrm{O}_{3}-\mathrm{SiO}_{2}$ [9]. Из диаграммы состояния системы $\mathrm{FeO}-\mathrm{Al}_{2} \mathrm{O}_{3}-\mathrm{SiO}_{2}$ следует, что составы фракций ферросфер соответствуют относительно низкоплавким (1100-1300 ${ }^{\circ} \mathrm{C}$ ) составам границ областей кристаллизации вюстита $\mathrm{FeO}$, фаялита $2 \mathrm{FeO} \cdot \mathrm{SiO}_{2}$, железистого кордиерита $2 \mathrm{FeO} \cdot 2 \mathrm{Al}_{2} \mathrm{O}_{3} \cdot 5 \mathrm{SiO}_{2}$ и герцинита $\mathrm{FeO} \cdot \mathrm{Al}_{2} \mathrm{O}_{3}$ [9]. Важным фактором в формировании структуры ферросфер служит вязкость расплавов, в частности, с увеличением содержания железа от 35 до 70 \% происходит значительное уменьшение вязкости (в 20 раз при $1200{ }^{\circ} \mathrm{C}$ [13]) железоалюмосиликатных расплавов. Установлено, что с увеличением валового содержания железа от 35 до 70 \% меняется основной морфологический тип ферросфер - от пенистых глобул с высокой пористостью до массивных с преобладанием дендритной структуры кристаллитов феррошпинели $[8,9]$.

В работах [7, 14] показана возможность создания композитных магнитных $\mathrm{Ni}^{2+}$ мезопористых силикатных и $\mathrm{Ni}^{2+}$-цеолитных сорбентов для выделения рекомбинантных белков с использованием в качестве магнитного ядра ферросфер фракции $-0,063+0,05$ мм, выделенной из летучей золы экибастузского угля. Синтез мезопористого кремнеземного покрытия на поверхности ферросфер осу-ществлен темплатным методом в гидротермальных условиях и спиртово-аммиачной среде с использованием тетраэтоксиси-лана. Создание цеолитной оболочки выполнено обработкой ферросфер в щелочной среде и гидротермальных условиях без внешних источников Si- и Al- за счет растворения части алюмоси-ликатного стекла в щелочном растворе. Последней стадией получения сорбентов является инкорпорирование ионов $\mathrm{Ni}^{2+}$ 
в мезопористую силикатную или цеолитную оболочку [14]. Стеклофаза служит своего рода защитной матрицей, препятст-вующей окислению магнитного компонента и его потенциально возможному растворению в случае контактирования с водными средами. Наряду с этим, силикатное стекло содержит на своей поверхности реакционноспо-собные силанольные группы $\equiv \mathrm{Si}-\mathrm{OH}$, которые могут служить якорными группами для закрепления катионов d-металлов по типу координационного взаимодействия или, в случае их невысокого содержания, для связывания дополнительного функционального слоя высокой поверхности.

Целью данной работы является исследование состава индивидуальных ферросфер основных морфологических типов во фракциях, полученных из летучей золы от промышленного пылевидного сжигания экибастузского угля, анализ прекурсоров минеральных форм и маршрутов их превращения.

\section{Экспериментальная часть}

Исследовались фракции ферросфер $-0,063+0,05$ и $-0,05$ мм, выделенные из летучей золы типа $\mathrm{S}$ (алюмосиликатный) от сжигания экибастузского угля на ТЭЦ-4 г. Омска в котлах БКЗ-420-140 жидкого шлакоудаления с температурой в зоне ядра факела около $1700{ }^{\circ} \mathrm{C}$ [8]. Отбор летучей золы проводился с 1-го и 2-го полей электрофильтров системы очистки отходящих газов. Способы получения фракций, методы химического и количественного фазового анализов подробно описаны в [8,9], данные для исследуемых фракций приведены в табл. 1 и 2.

Общий вид фракций показан на снимках (рис. 1a, б), полученных с помощью электронных микроскопов TM-1000 и TESLA BS-35.

Оценка содержания морфологических типов ферросфер во фракциях выполнена по электронно-микроскопическим снимкам полированных срезов, приготовленных путем фиксации фракций ферросфер в эпоксидной смоле с последующей шлифовкой и полировкой с использованием материалов и оборудования компании STRUERS (Дания). На поверхность шлифов на-

Таблица 1. Химический состав фракций (мас. \%)

\begin{tabular}{|c|c|c|c|c|c|c|c|c|c|}
\hline Фракция, мм & $\mathrm{SiO}_{2}$ & $\mathrm{Al}_{2} \mathrm{O}_{3}$ & $\mathrm{FeO}$ & $\mathrm{CaO}$ & $\mathrm{MgO}$ & $\mathrm{Na}_{2} \mathrm{O}$ & $\mathrm{K}_{2} \mathrm{O}$ & $\mathrm{TiO}_{2}$ & $\mathrm{SO}_{3}$ \\
\hline$-0,063+0,05$ & 27,34 & 9,75 & 55,58 & 2,91 & 1,11 & 0,97 & 0,21 & 1,45 & 0,69 \\
\hline$-0,05$ & 20,21 & 8,83 & 67,56 & 2,06 & 1,06 & 0,11 & 0,14 & $<0,01$ & 0,02 \\
\hline
\end{tabular}

Таблица 2. Фазовый состав фракций (мас. \%) и параметры кристаллической решетки (А́) феррошпинели $\left(a_{f}\right)$ и гематита $\left(a_{h}\right.$ и $\left.c_{h}\right)$

\begin{tabular}{|c|c|c|c|c|c|c|c|c|c|c|}
\hline \multirow{2}{*}{ Фракция, мм } & \multirow{2}{*}{ 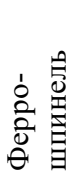 } & \multirow{2}{*}{ 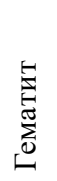 } & \multirow[b]{2}{*}{ 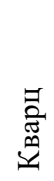 } & \multirow{2}{*}{ 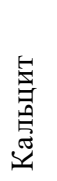 } & \multirow{2}{*}{$\begin{array}{l}5 \\
\stackrel{5}{S} \\
\stackrel{5}{\Sigma}\end{array}$} & \multirow{2}{*}{ 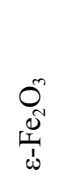 } & \multirow{2}{*}{ 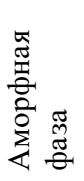 } & \multirow{2}{*}{$\begin{array}{c}\text { Ферро- } \\
\text { шпинель }\end{array}$} & \multicolumn{2}{|c|}{ Гематит } \\
\hline & & & & & & & & & $a_{h}$ & $c_{h}$ \\
\hline$-0,063+0,05$ & 48,8 & 2,9 & 3,1 & 0,1 & 3,5 & 0,4 & 41,2 & $8,366(1)$ & $5,032(1)$ & $13,727(4)$ \\
\hline$-0,05$ & 45,6 & 4,3 & 2,6 & 0,0 & 2,9 & 2,8 & 41,8 & $8,360(1)$ & $5,0302(6)$ & $13,729(3)$ \\
\hline
\end{tabular}



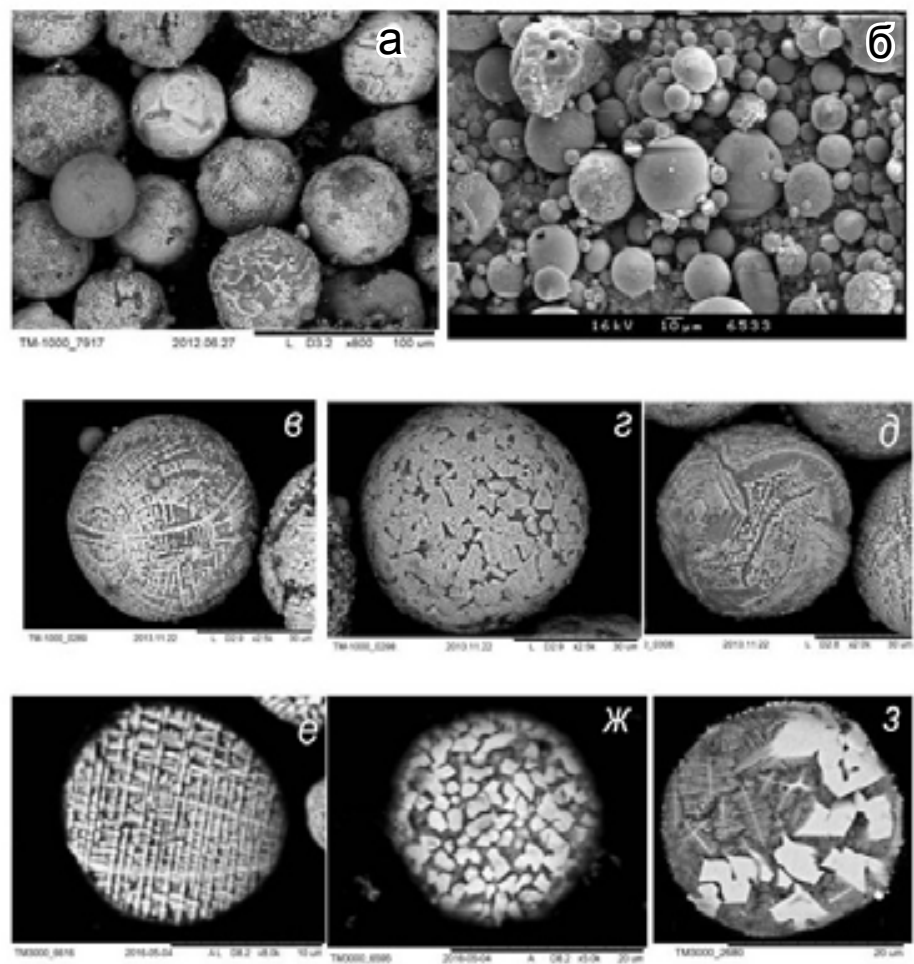

Рис. 1. Электронно-микроскопические снимки фракций $-0,063+0,05$ (а) и -0,05 мм (б), поверхности (в-д) и срезов (е-з) индивидуальных ферросфер трех типов : в, е - дендритный; г, ж-блочный; д, 3 - дендритноблочный

пыляли 20 нм слой платины. Для индивидуальных ферросфер определяли брутто-составы по полному сечению глобул и составы локальных участков с $\mathrm{d} \approx 4$ мкм на перпендикулярных диаметрах, как описано в работах $[15,16]$, а также составы кристаллических и межкристаллитных аморфных участков с использованием электронного микроскопа TM-3000 (Hitachi, Япония), оснащенного энергодисперсионной системой микроанализа QUANTAX 70 (BRUKER, Германия), с разрешением 30 нм при ускоряющем напряжении 15 кВ и времени накопления 10 мин. Элементный состав пересчитывали на оксиды, железо - на FеO, сумму приводили к 100 \%.

\section{Результаты и обсуждение}

В процессе пылевидного промышленного сжигания угля при температурах $1100-1600{ }^{\circ} \mathrm{C}$ железо в высокожелезистых расплавах находится преимущественно в виде $\mathrm{Fe}(\mathrm{II})$, что способствует снижению температуры плавления и вязкости расплавов $[13,17]$. Для установления взаимосвязи состав-строение индивидуальных ферросфер во фракциях, полученных из высококальциевых зол типа CS [15], использовалась величина модуля основности расплавов $\mathrm{M}_{\mathrm{o}}=(\mathrm{FeO}+\mathrm{CaO}+\mathrm{MgO}) /\left(\mathrm{SiO}_{2}+\mathrm{Al}_{2} \mathrm{O}_{3}\right)$, включающая соотношение элементов-модификаторов $(\mathrm{Fe}, \mathrm{Ca}, \mathrm{Mg}$ ) относительно элементов-стеклообразователей ( $\mathrm{Si}, \mathrm{Al})$. С увеличением величины $\mathrm{M}_{\text {o }}$ снижается вязкость и увеличивается линейная скорость роста кристаллов при охлаждении силикатных и алюмосиликатных расплавов $[13,15,16]$. Установлено, что при $\mathrm{M}_{\mathrm{o}}>33$ образуются моноблочные глобулы, при $\mathrm{M}_{\mathrm{o}}=28$ преобладают пластин-чатые глобулы со структурой 
ядро-оболочка, в которой ядро обра-зовано блоками феррошпинели, а оболочка пластинчатой структуры образована фазами $\mathrm{Fe}_{2} \mathrm{O}_{3}, \mathrm{CaFe}_{2} \mathrm{O}_{4}$ и $\mathrm{CaFe}_{4} \mathrm{O}_{7}$ [16]. При $\mathrm{M}_{\mathrm{o}}$ 11-14 происходит образование дендритных глобул.

\section{Характеристика исходных фракций ферросфер}

В химическом составе фракций $-0,063+0,05$ и $-0,05$ мм содержание оксидов железа составляет 55,58 и 67,56 мас. \% в расчете на $\mathrm{FeO}$ (табл. 1). В число трех главных компонентов входят также $\mathrm{SiO}_{2}\left(27,34\right.$ и 20,21 мас. \%) и $\mathrm{Al}_{2} \mathrm{O}_{3}$ (9,75 и 8,83 мас. \%), а сумма $\mathrm{FeO}+\mathrm{SiO}_{2}+\mathrm{Al}_{2} \mathrm{O}_{3}$ составляет 92,66 и 96,6 мас. \% соответственно. Образование кристаллических фаз при охлаждении расплавленного вещества ферросфер происходит при повышении окислительного потенциала, поэтому часть железа $\mathrm{Fe}(\mathrm{II})$ окисляется до $\mathrm{Fe}(\mathrm{III})$, а в качестве главной фазы образуется феррошпинель, содержание которой составляет 48,8 и 45,6 мас. \% во фракциях $-0,063$ $+0,05$ и $-0,05$ мм соответственно (табл. 2). Небольшая часть железа присутствует в виде более окисленных форм - гематита $\alpha-\mathrm{Fe}_{2} \mathrm{O}_{3}$ и $\varepsilon-\mathrm{Fe}_{2} \mathrm{O}_{3}$. Согласно [8] часть железа феррошпинели замещена на $\mathrm{Al}$ и $\mathrm{Mg}$, о чем свидетельствует более низкий параметр кристаллической решетки (8,366 и 8,360 А̊) по сравнению с чистым магнетитом $\mathrm{Fe}_{3} \mathrm{O}_{4}(8,396 \AA)$. Из сопоставления данных химического и фазового составов фракций следует, что железо входит также в состав аморфного вещества в состоянии $\mathrm{Fe}^{2+}$, это вытекает из данных мессбауэровских исследований фракций ферросфер [18]. Исходя из того, что содержание фаз кварца $\alpha-\mathrm{SiO}_{2}$ и муллита $3 \mathrm{Al}_{2} \mathrm{O}_{3} \cdot 2 \mathrm{SiO}_{2}$ мало $(2,6-3,5 \%)$, основная часть кремния и алюминия входит в аморфное вещество, составляющее около 41 и 42 \% в изученных фракциях.

Морфологический состав изученных фракций $-0,063+0,05$ и $-0,05$ мм (по оценке $~ 1100$ ферросфер) включает три основных типа глобул, примеры которых представлены на рис. 18-3дендритных 48 и $63 \%$, блочных 15 и $10 \%$, дендритно-блочных 13 и $6 \%$, что в сумме равно 76 и 79 \% соответственно. В оставшуюся часть входят (по убыванию) пенистые, плеросферы, сплавленные, моноблочные и пластинчатые глобулы. Для трех типов (дендритные, блочные и дендритно-блочные) определены брутто-составы по срезам глобул и составы локальных участков, включая состав кристаллитов феррошпинели и межкристаллитного аморфного вещества.

\section{Состав и строение индивидуальных ферросфер}

Из данных растровой электронной микроскопии и рентгеноспектрального микроанализа с картированием срезов ферросфер следует, что наблюдается общая зависимость $\mathrm{M}_{\mathrm{o}}=\mathrm{f}[\mathrm{FeO}$, где $\mathrm{M}_{\mathrm{o}}=(\mathrm{FeO}+\mathrm{CaO}+\mathrm{MgO}) /\left(\mathrm{Al}_{2} \mathrm{O}_{3}+\mathrm{SiO}_{2}\right)$, для брутто-составов 3-х типов глобул (рис. $\left.2 a\right)$. При этом составы дендритных глобул отвечают наиболее широкому диапазону содержаний $\mathrm{FeO} 32-87$ \% и $\mathrm{M}_{\circ}$ 0,5-12, тогда как отдельные блочные глобулы в интервалах концентраций $\mathrm{FeO} 38-52$ \% и 7275 \% характеризуются при этом более высокой величиной Мо по сравнению с дендритными.

Для трех типов ферросфер наблюдается также общая зависимость $\left[\mathrm{SiO}_{2}\right]=f[\mathrm{FeO}]$, описываемая уравнением линейной регрессии $\left[\mathrm{SiO}_{2}\right]=67,42-0,73 \cdot[\mathrm{FeO}]$ с коэффициентом корреляции $\mathrm{r}=-0,97$ (рис. 26). Следует отметить, что уравнение, полученное для индивидуальных ферросфер, близко уравнению $\left[\mathrm{SiO}_{2}\right]=65,71-0,71 \cdot\left[\mathrm{Fe}_{2} \mathrm{O}_{3}\right] \mathrm{c} \mathrm{r}=-0,99$, полученному для фракций ферросфер в работе [8], основанному на данных химического анализа. Наблюдаются отдельные блочные глобулы в интервале $\mathrm{FeO} 38-52$ и 72-75 мас. \% с пониженным относительно общей 

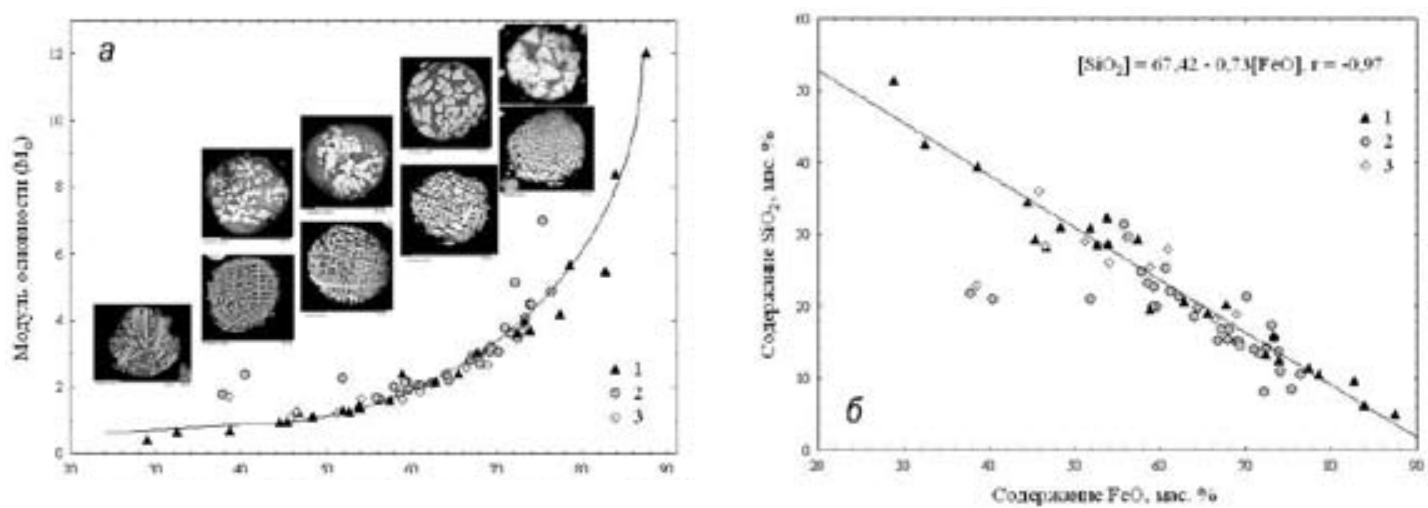

Рис. 2. Зависимость модуля основности $\mathrm{M}_{\text {o }}$ (а) и содержания $\mathrm{SiO}_{2}$ (б) от содержания $\mathrm{FeO}$ по бруттосоставам полированных срезов ферросфер трех типов

зависимости содержанием $\mathrm{SiO}_{2}$ (рис. 2б). Эти же глобулы отличаются повышенным модулем основности $\mathrm{M}_{\text {о }}$ за счет более высокого содержания $\mathrm{CaO}$ и $\mathrm{MgO}$ на зависимости $\mathrm{M}_{\mathrm{o}}=f[\mathrm{FeO}]$, приведенной на рис. $2 a$.

Важную роль в образовании структуры ферросфер играет $\mathrm{Al}_{2} \mathrm{O}_{3}$, который одновременно является и модификатором и сеткообразо-вателем в исходном высокожеле-зистом силикатном расплаве. Алюминий, подобно железу, вхо-дит в состав и кристаллических шпинелидов и стеклофазы. Несмотря на относительно низкое содержание $\mathrm{MgO}$ во фракциях ферросфер (около $1 \%$ ), он также может в значительной мере влиять на строение глобул, как было установлено при исследовании индивидуальных ферросфер, выделенных из высококальциевых зол $[15,16]$. Превалирующим типом глобул в исследованных фракциях являются дендритные, которые состоят из тонких однонаправленных или разветвленных закономерно ориентированных сростков кристаллических индивидов феррошпинели (рис. $3 a$, ).

Сравнение дендритных и блочных ферросфер с близким содержанием компонентов $\mathrm{FeO}$, $\mathrm{SiO}_{2}, \mathrm{Al}_{2} \mathrm{O}_{3}$ (рис. 3) показало, что в дендритных глобулах 6670 и 6666 (рис. 3a, в) содержание $\mathrm{MgO}$ выше в кристаллитах (2,1-4,3 мас.\%) по сравнению со межкристаллитными аморфными участками (0,76-2,3 мас.\%). При низком содержании (3,2-3,5\% $\left.\mathrm{Al}_{2} \mathrm{O}_{3}\right)$ алюминий избира-тельно входит в структуру шпинелидов, тогда как при его валовом содержании около 9 мас.\% он распределяется при-мерно поровну между аморфной силикатной и кристаллической фазами. Ферросферы блочного типа 2694 и 6620 (рис. 36, г) состоят из крупных блоков феррошпинели, составы которых укладываются в узкий диапазон концентраций и приближаются к магнетиту. Содержание $\mathrm{Mg}$ и $\mathrm{Al}$ в 2-4 раза ниже в блоках феррошпинели, чем в межблоч-ном аморфном веществе.

\section{Прекурсоры и маршруты образования ферросфер}

Как уже было отмечено, главным прекурсором ферросфер в экибастузском угле выступает сидерит $\mathrm{FeCO}_{3}$, содержание которого по данным [11, 12] составляет около $10 \%$. При температурах $>585^{\circ} \mathrm{C}$ сидерит разлагается с выделением $\mathrm{CO}_{2}$ и образованием $\mathrm{Fe}, \mathrm{FeO}, \mathrm{Fe}_{2} \mathrm{O}_{3}$ в зависимости от парциального давления $\mathrm{O}_{2}, \mathrm{CO}$ и $\mathrm{CO}_{2}$ [19]. Из примесей в природном сидерите 

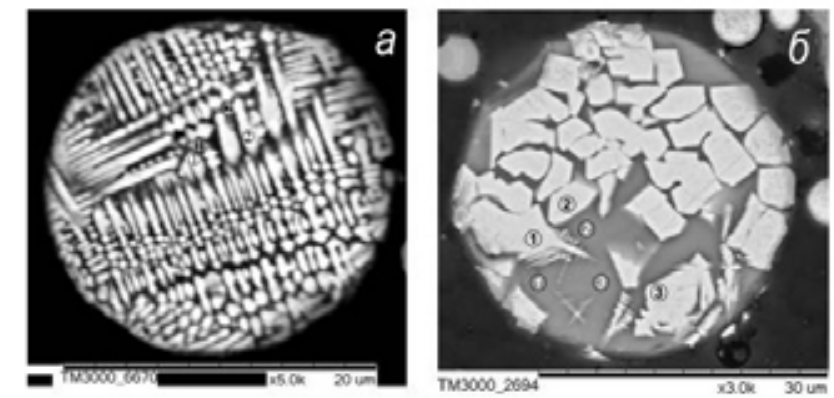

\begin{tabular}{|c|c|c|c|c|c|c|c|c|c|c|c|}
\hline & $\mathrm{FeO}$ & $\mathrm{SAO}_{3}$ & $\mathrm{Al}_{2} \mathrm{O}_{3}$ & $\mathrm{CaO}$ & $\mathrm{MgO}$ & & $\bar{F} \in \mathrm{O}$ & $\mathrm{SiO}_{2}$ & $\mathrm{Al}_{2} \mathrm{O}_{3}$ & $\mathrm{CaO}$ & $\mathrm{MgO}$ \\
\hline 6670 & 65.45 & 19.02 & 9.38 & 1.11 & 1.71 & 2694 & 64.32 & 19.81 & 11.09 & 3.72 & 0.51 \\
\hline $\mathrm{Kgl}$ & 70.67 & 14.42 & 10.12 & 0.39 & 2.08 & $\mathrm{Kpl}$ & 90.09 & 0.00 & 8.35 & 0.18 & 0.56 \\
\hline Axt & 7.66 & 27.19 & 9.55 & 1.70 & 0.94 & $A M 1$ & 22.24 & 48.28 & 17.58 & 8.29 & 1.22 \\
\hline $\mathrm{Kq2}$ & 69.96 & 11.80 & 10.32 & 0.76 & 2.29 & $\mathrm{Kp} 2$ & 89.34 & 1.32 & 8.02 & 0.00 & 0.50 \\
\hline$A M 2$ & 61.56 & 23.46 & 9.79 & 0.54 & 0.76 & Am & 20.36 & 49.18 & 16.05 & 10.74 & 1.00 \\
\hline $\mathrm{Kg} 3$ & 70.11 & 13.83 & 9.77 & 1.04 & 2.19 & $\mathrm{Kp3}$ & 90.69 & 0.39 & 6.83 & 0.21 & 0.17 \\
\hline$A x^{3}$ & 57.26 & 30.61 & 8.89 & 2.43 & 0.53 & AM3 & 23.84 & 46.34 & 15.84 & 10.87 & 1.00 \\
\hline
\end{tabular}
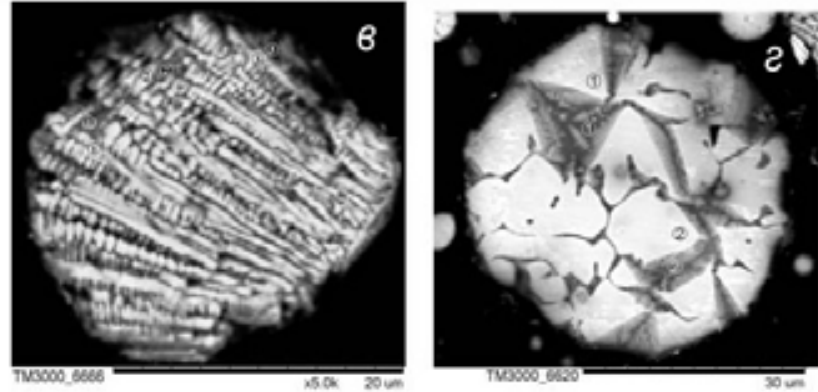

\begin{tabular}{|c|c|c|c|c|c|c|c|c|c|c|c|}
\hline & $\mathrm{S}_{4} \mathrm{O}_{2}$ & $\mathrm{Al}_{2} \mathrm{O}_{3}$ & $\mathrm{~F} \in \mathrm{O}$ & $\mathrm{CaO}$ & $\mathrm{MgO}$ & & $\mathrm{SiO}_{2}$ & $\mathrm{Al}_{2} \mathrm{O}_{3}$ & FeO & $\mathrm{C}_{3} \mathrm{O}$ & $\mathrm{MgO}$ \\
\hline 6666 & 16.08 & 3.22 & 73.19 & 0.97 & 3.33 & 6620 & 15.52 & 3.48 & 73.2 & 1.5 & 3.04 \\
\hline $1 \mathrm{Cr}$ & 13.10 & 2.90 & 74.63 & 1.07 & 4.34 & $1 \mathrm{Cr}$ & 2.80 & 1.72 & 90.95 & 0.34 & 1.96 \\
\hline $1 \mathrm{Gl}$ & 28.56 & 2.66 & 60.57 & 0.90 & 2.27 & $1 \mathrm{Gl}$ & 53.80 & 7.39 & 23.64 & 6.96 & 5.04 \\
\hline $2 \mathrm{Cr}$ & 8,89 & 3,75 & 77,31 & 0,89 & 4,23 & $2 \mathrm{Cr}$ & 2,84 & 2,37 & 89,85 & 0,03 & 1,71 \\
\hline $2 \mathrm{Gl}$ & 19.84 & 1.76 & 71.16 & 1.44 & 2.32 & $2 \mathrm{Gl}$ & 48.55 & 8.22 & 29,49 & 6.01 & 3.89 \\
\hline $3 \mathrm{Cr}$ & 11.24 & 3.20 & 77.24 & 1.16 & 3.69 & & & & & & \\
\hline $3 \mathrm{Gl}$ & 14,39 & 2,58 & 77,19 & 1,26 & 1,92 & & & & & & \\
\hline
\end{tabular}

Рис. 3. Электронно-микроскопические снимки срезов и состав кристаллических (Кр) и межкристаллитных аморфных (Ам) участков в дендритной $(\mathrm{a}, \mathrm{B})$ и блочной $(б, \Gamma)$ глобулах близкого брутто-состава

чаще всего присутствуют $\mathrm{Ca}, \mathrm{Mg}, \mathrm{Mn}[20]$, при этом расплавленное состояние при температуре около $1600{ }^{\circ} \mathrm{C}$ достигается при содержании $\mathrm{MgO}<5$ мас. \% [21].

Основным процессом термохимических превращений минеральной части экибастузского угля является взаимодействие $\mathrm{FeO}$ - главного продукта разложения сидерита в умеренно восстановительной газовой среде с продуктами термической аморфизации слоистых силикатов и кварца. Из диаграммы рис. 4 видно, что подавляющая часть точек состава индивидуальных глобул дендритного, блочного типов и со смешанной структурой проецируется на границы областей кристаллизации вюстита $\mathrm{FeO}$, фаялита $2 \mathrm{FeO} \cdot \mathrm{SiO}_{2}$, железистого кордиерита $2 \mathrm{FeO} \cdot 2 \mathrm{Al}_{2} \mathrm{O}_{3} \cdot 5 \mathrm{SiO}_{2}$ и герцинита $\mathrm{FeO} \cdot \mathrm{Al}_{2} \mathrm{O}_{3}$ с температурами плавления в интервале $1100-1300{ }^{\circ} \mathrm{C}$.

Следует отметить, что наблюдается хорошее соответствие между составами индивидуальных глобул (рис. 4) и фракций на диаграмме $\mathrm{FeO}-\mathrm{Al}_{2} \mathrm{O}_{3}-\mathrm{SiO}_{2}$, представленных в работе [9]. В отличие от работы [9] на диаграмме рис. 4 отсутствуют высокожелезистые (FeO $>90$ \%) ферросферы, полученные из высококальциевой летучей золы березовского угля Канско-Ачинского 


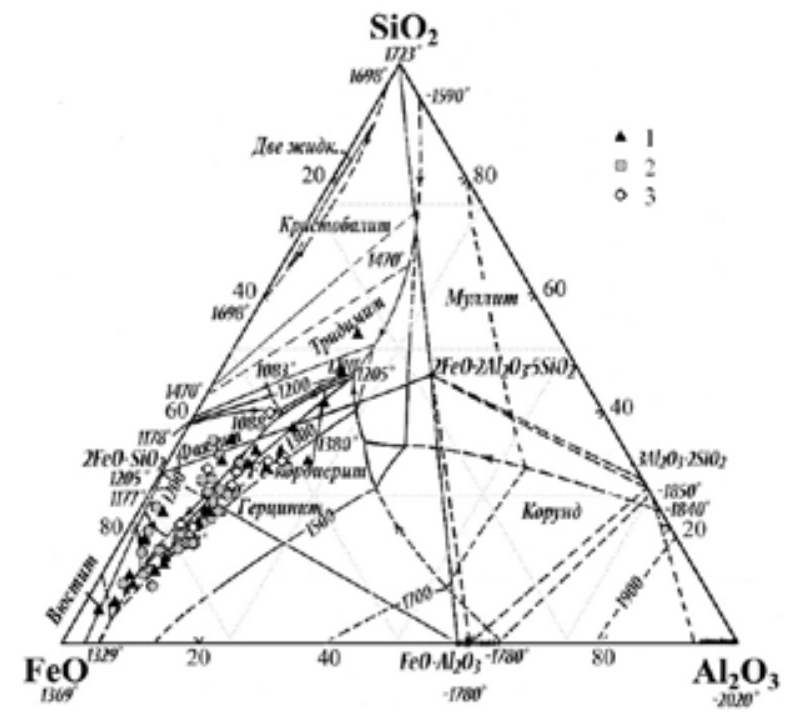

Рис. 4. Диаграмма состояния тройной системы $\mathrm{FeO}-\mathrm{Al}_{2} \mathrm{O}_{3}-\mathrm{SiO}_{2}$ с нанесенными точками брутто-составов ферросфер трех типов: 1 - дендритный; 2 - блочный, 3 - дендритно-блочный

бассейна, среди которых преобладают моноблочные глобулы с содержанием общего железа 94-97 мас. \% FeO $[15,16]$. Они состоят из частично мартитизованной феррошпинели и образованы из мономинеральных зерен пирита с минимальным содержанием примесей [16].

Наиболее характерным морфологическим типом ферросфер в изученных фракциях являются дендритные глобулы. Они образуются из продуктов разложения тонкодисперсного сидерита, в разной степени ассоциированного с тонковкрапленными кварцем и алюмосиликатами. В результате расплавления, охлаждения и кристаллизации расплавов в них образуется структура из тонких однонаправленных или разветвленных кристаллических индивидов $\mathrm{Al}$, $\mathrm{Mg}$-ферритовой шпинели, капсулированных в железоалюмосиликатном стекле. Ферросферы блочного типа образуются с участием более крупных включений сидерита, продукты разложения которого взаимодействуют с диспергированными в угольной матрице кварцем и алюмосиликатами. В условиях быстрого высокотемпературного нагрева гомогенизация расплава также не достигается, при этом сохраняются достаточно большие локальные участки, обогащенные железом, которые при охлаждении образуют блоки кристаллов феррошпинели с меньшим количеством примесей. В результате коалесценции капель расплавов, образовавшихся из сидерита разной дисперсности, формируются ферросферы смешанной структуры. Таким образом, важным фактором, влияющим на строение ферросфер, признана дисперсность их главного прекурсора - сидерита $\mathrm{FeCO}_{3}$.

\section{Заключение}

Изучены фракции ферросфер -0,063+0,05 и -0,05 мм, полученные из промышленной летучей золы от сжигания каменного угля Экибастузского бассейна на ТЭЦ-4 г. Омска. Установлено, что главная фаза ферросфер - феррошпинель (48,8 и 45,6 мас. \%), в которой часть железа замещена на $\mathrm{Al}^{3+}$ и $\mathrm{Mg}^{2+}$, о чем свидетельствует более низкий параметр кристалличе- 


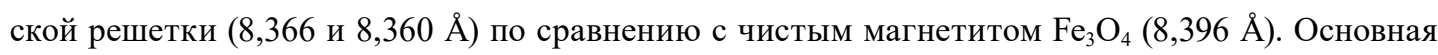
часть кремния, алюминия и значительная часть железа входят в состав аморфного вещества, составляющего около 41 и $42 \%$ в изученных фракциях. Методами растровой электронной микроскопии и энергодисперсионной рентгеновской спектроскопии с картированием полированных срезов определен брутто-состав индивидуальных ферросфер дендритного, блочного и дендритно-блочного строения, составляющих около 80 \% изученных фракций. Установлено, что их брутто-составы подчиняются общей зависимости $\mathrm{M}_{\mathrm{o}}=f[\mathrm{FeO}]$ и соответствуют относительно низкоплавким $\left(1100-1300{ }^{\circ} \mathrm{C}\right)$ точкам состава границ областей кристаллизации вюстита $\mathrm{FeO}$, фаялита $2 \mathrm{FeO} \cdot \mathrm{SiO}_{2}$, железистого кордиерита $2 \mathrm{FeO} \cdot 2 \mathrm{Al}_{2} \mathrm{O}_{3} \cdot 5 \mathrm{SiO}_{2}$ и герцинита $\mathrm{FeO} \cdot \mathrm{Al}_{2} \mathrm{O}_{3}$ в диаграмме состояния $\mathrm{FeO}-\mathrm{Al}_{2} \mathrm{O}_{3}-\mathrm{SiO}_{2}$. Превалирующим типом глобул являются дендритные (48-63 \%), которые состоят из тонких однонаправленных или разветвленных кристаллических индивидов $\mathrm{Al}, \mathrm{Mg}$-ферритовой шпинели. Содержание $\mathrm{Mg}$ в 2-3 раза и $\mathrm{Al}$ в 1,1-2,1 раза выше в дендритах феррошпинели по сравнению с участками межкристаллитного аморфного вещества. Они образованы из продуктов разложения тонкодисперсного сидерита, в разной степени ассоциированного с тонковкрапленным кварцем и алюмосиликатами. Ферросферы блочного типа образованы из более крупных включений сидерита и диспергированных в угольной матрице кварца и алюмосиликатов. При близком составе с дендритными они имеют более крупные, высокожелезистые и достаточно узкие блоки феррошпинели, в которых, напротив, содержание $\mathrm{Mg}$ и $\mathrm{Al}$ в 2-4 раза ниже, чем в межблочном аморфном веществе.

\section{Список литературы}

1. Вдовченко В.С., Мартынова М.И., Новицкий Н.В., Юшина Г.Д. Энергетическое топливо СССР. Справочник. М.: Энергоатомиздат, 1991. 184 с. [Vdovchenko V.S., Martynova M.I., Novitsky N.V., Yushina G.D., Power fuel in the USSR. Handbook, Moscow: Energoatomizdat, 1991. 184 p. (In Russ.)]

2. Кизильштейн Л.А., Дубов И.В., Шпицглуз А.Л., Парада С.Г. Компоненты зол и шлаков ТЭС. М.: Энергоатомиздат. 1995. 176 с. [Kizil'shtein L.Ya., Dubov I.V., Shpitsgluz A.L., Parada S.G. Components of ashes and slags of heat power plants. Moscow: Energoatomizdat, 1995. 176 p. (In Russ.)]

3. Blissett R.S.; Rowson N.A. A review of the multi-component utilization of coal fly ash. Fuel 2012. V. 97, P. 1-23.

4. Fedorova N.V., Shaforost D.A. Prospects for using the fly ash produced at thermal power plants in the Rostov region. Thermal Engineering. 2015. Vol. 62 (1), P. 51-57.

5. Anshits A.G., Anshits N.N., Rabchevskii E.V., Vereshchagin S.N., Bayukov O.A., Pletnev O.N., Kondratenko E.V. Nature of the active sites of ferrospheres in oxidative condensation of methane. Kinet. Catal. 2015. Vol. 56(4), P. 523-531.

6. Golovko A.K., Kopytov M.A., Sharonova O.M., Kirik N.P., Anshits A.G. Cracking of heavy oils using catalytic additives based on coal fly ash ferrospheres. Catalysis in Industry. 2015. Vol. 7(4), P. 293-300.

7. Fedorchak M.A., Sharonova O.M. Mazurova Ye.V., Vereshchagina T.A., Anshits A.G. Magnetic affine sorbents for the isolation of recombinant proteins. Inorganic Materials: Applied Research. 2016. Vol. 7(2), P. 233-239. 
8. Sharonova O.M., Anshits N.N., Solovyov L.A., Salanov A.N., Anshits A.G. Relationship between composition and structure of globules in narrow fractions of ferrospheres. Fuel 2013. V. 111, P. 332-343.

9. Sharonova O.M., Anshits N.N., Anshits A.G. Composition and morphology of narrowly sized ferrospheres isolated from various types of fly ash. Inorganic Materials. 2013, Vol. 49(6), P. 586-594.

10. Шпирт М.Я., Клер В.Р., Перциков И.З. Неорганические компоненты твердых топлив. М.: Химия, 1990. 240 с. [Shpirt M.J., Clair V.R., Persikov I.Z. Inorganic components of solid fuels. Moscow: Publishing House Khimija, 1990. 240 p. (In Russ.)]

11. Геология месторождений угля и горючих сланцев СССР. Т. 5. Угольные бассейны и месторождения Казахстана. Книга 1. Бассейны и месторождения палеозойского возраста. М: Недра, 1973. 720 c. [Geology of coal deposits and combustible shales of the USSR. Vol. 5. Coal pools and deposits of Kazakhstan. Book 1. Pools and deposits of Paleozoic age. Moscow: Nedra, 1973. 720 p. (In Russ.)]

12. Вдовенко М.И. Минеральная часть энергетических углей (физико-химическое исследование). Алма-Ата Казахской ССР: Наука, 1973. 256 с. [Vdovenko M.I., The mineral part of energy coals (physicochemical research). Alma-Ata, Kazakhstan: Nauka, 1973. 256 p. (In Russ.)]

13. Kondratiev A., Jak E. Quasi-chemical viscosity model for fully liquid slags in the $\mathrm{Al}_{2} \mathrm{O}_{3}-\mathrm{CaO}-' \mathrm{FeO}$ - $-\mathrm{SiO}_{2}$ system. Metall. Mater. Trans. B 2005. V. 36, P. 623-638.

14. Vereshchagina T.A., Fedorchak M.A., Sharonova O.M., Fomenko E.V., Shishkina N.N., Zhizhaev A.M., Kudryavtsev A.N., Frank L.A., Anshits A.G. $\mathrm{Ni}^{2+}$-zeolite/ferrosphere and $\mathrm{Ni}^{2+}$-silica/ ferrosphere beads for magnetic affinity separation of histidine-tagged proteins. Dalton Transaction 2016. V. 45, P. 1582-1592.

15. Sharonova O.M., Fedorchak M.A., Zhizhaev A.M., Mazurova E.V., Anshits A.G. Composition of individual ferrospheres of different morphological types. Inorganic Materials. 2015. Vol. 51(11), P. 1143-1150.

16. Sharonova O.M., Anshits N.N., Fedorchak M.A.,Zhizhaev A.M., Anshits A.G. Characterization of ferrospheres recovered from high-calcium fly ash. Energy \& Fuels 2015. V. 29, P. 5404-5414.

17. Sokol E.V., Kalugin V.M., Nigmatulina E.N., Volkova N.I., Frenkel A.E., Maksimova N.V. Ferrospheres from fly ashes of Chelyabinsk coals: chemical composition, morphology and formation conditions. Fuel 2002. V. 81, P. 867-876.

18. Bayukov O.A., Anshits N.N., Balaev A.D., Sharonova O.M., Rabchevskii E.V., Petrov M.I., Anshits A.G. Mössbauer study of magnetic microspheres isolated from power plant fly ash. Inorganic Materials. 2005. Vol. 41(1), P. 50-59.

19. Bryers R.W. Fireside slagging, fouling and high-temperature corrosion of heat-transfer surface due to impurities in steam-raising fuels. Progr. Energy Combust. Sci. 1996. V. 22, P. 29-120.

20. Бетехтин А.Г. Курс минералогии. М.: Госгеолтехиздат, 1961. 540 c. [Betekhtin A.G. A course of mineralogy. Moscow: Gosgeltekhizdat, 1961. 540 p. (In Russ.)]

21. Impact of mineral impurities in solid fuel combustion. Edited by Gupta R., Wall T., Baxter L. New York, Boston, Dordrecht, London, Moscow: Kluwer Academic Publishers, 2002. 781 p. 